\title{
ANALISA DAMPAK KEBIJAKAN PENURUNAN TARIF PAJAK PENGHASILAN (PPh) FINAL UNTUK UMKM TERHADAP PENERIMAAN PAJAK NEGARA DI KOTA BATAM PROV. KEPRI
}

\author{
Afrianti Elsye Vanomy ${ }^{1}$ \\ Program Studi Manajemen, Fakultas Bisnis, Universitas Universal Batam \\ Email : yanti.elva803@gmail.com ${ }^{1}$
}

Dibiayai oleh : Deputi Bidang Penguatan Riset dan Pengembangan Kementerian Riset dan Teknologi

/ Badan Riset dan Inovasi Nasional

\begin{abstract}
This study aims to determine whether MSMEs in Batam have implemented PP No. 23 of 2018 according to the form of business or business profile the impact of this rate reduction of this rate reduction on tax revenue at KPP Pratama Batam Selatan. Data obtained from distributing questionnaires via Google form and interviews and direct data collection at KPP Pratama Batam Selatan. The sampling method of this research is purposive sampling technique.and uses descriptive quantitative by investigating the influence of the MSME business profile variable on State Revenue through taxpayer compliance. State revenue data comes from PPh 4 paragraph 2 specifically for MSMEs with PP. No. 46 of 2013 and PP No. 23 of 2018 over period of 4 years, namely 2016 to 2019. And using regression and path analysis. So that the results of this study indicate that the business profile is significant on taxpayer compliance, as well as the significant result between taxpayer compliance with state revenue, but business profile has no significant effect on State Revenue, the effect is direct, but the results differ if the effect of business profile on State Revenue through compliance. The result of taxpayers is significant.
\end{abstract}

Keywords : MSME, tax rate reduction, final income tax, State Tax Revenue.

\begin{abstract}
ABSTRAK
Penelitian ini bertujuan untuk mengetahui apakah UMKM di Batam telah menerapkan PP No. 23 Tahun 2018 sesuai bentuk usaha atau profil usaha dampak penurunan tarif ini terhadap penerimaan pajak di KPP Pratama Batam Selatan. Data diperoleh dari penyebaran kuesioner melalui Google form dan wawancara serta pengumpulan data langsung di KPP Pratama Batam Selatan. Metode pengambilan sampel dalam penelitian ini adalah teknik purposive sampling. Dan menggunakan deskriptif kuantitatif dengan mengetahui pengaruh variabel profil bisnis UMKM terhadap Pendapatan Negara melalui kepatuhan wajib pajak. Data penerimaan negara bersumber dari PPh 4 ayat 2 khusus untuk UMKM dengan PP No. Nomor 46 Tahun 2013 dan PP Nomor 23 Tahun 2018 selama periode 4 tahun yaitu tahun 2016 sampai dengan 2019. Serta menggunakan analisis regresi dan jalur. Sehingga hasil penelitian ini menunjukkan bahwa profil bisnis berpengaruh signifikan terhadap kepatuhan wajib pajak, serta terdapat hasil yang signifikan antara kepatuhan wajib pajak dengan penerimaan negara, namun profil bisnis tidak berpengaruh signifikan terhadap Pendapatan Negara, pengaruhnya langsung, tetapi hasilnya berbeda jika pengaruh profil bisnis terhadap Pendapatan Negara melalui kepatuhan wajib pajak hasilnya signifikan.
\end{abstract}

Kata kunci: UMKM, penurunan tarif pajak, pajak penghasilan final, Penerimaan Pajak Negara. 


\section{PENDAHULUAN}

Dewasa ini Pemerintah mulai melirik UMKM (usaha mikro kecil dan menengah) dengan alasan bahwa jumlah UMKM yang begitu besar di Indonesia, mampu menopang 99\% perekonomian, bila dibandingkan dengan Perusahaan-perusahaan besar jumlahnya memang tidak sebanding dari sisi laba maupun peredaran brutonya, namun karena jumlahnya yang cukup banyak ini, sehingga mampu memberikan kontribusi yang begitu besar terhadap Produk Domestik Bruto (PDB). (Setiawan, n.d.). Sehingga dirasa bahwa mampu memberikan potensi yang besar terhadap peningkatan penerimaan negara. Sehingga mampu pada akhirnya diharapkan bisa menyelesaikan berbagai macam permasalahan seperti mengurangi angka kemiskinan, mengurangi jumlah pengangguran, dan ketimpangan distribusi pendapatan. Oleh karena itu Pemerintah memberikan bantuan untuk memperingan beban UMKM dari sisi perpajakan, dengan mengeluarkan PP No. 23 tahun 2018 yang merupakan penggantian dari PP No. 46 tahun 2013 yang mana memberlakukan penurunan tarif Pajak Penghasilan Final untuk UMKM yang semula sebesar $1 \%$ menjadi $0,5 \%$ yang sudah diberlakukan sejak 01 Juli 2018, cakupan para pelaku UMKM dalam hal ini adalah para pengusaha yang memiliki bisnis UMKM dengan batasan plafon peredaran bruto sebesar 4,8M / tahun. Tujuan Pemerintah adalah mengajak para pelaku UMKM untuk masuk ke ranah formal supaya menjadi tax payer.

Tabel 1. perkembangan PDB UMKM dan Usaha Besar pada kurun waktu tahun 2014- 2018

\begin{tabular}{|c|c|c|c|c|c|c|}
\hline \multirow{2}{*}{ Jenis Usha } & \multicolumn{5}{|c|}{ PDB atas harrga (Miliar Rupiah) } & \multirow{2}{*}{ ta-rata } \\
\hline & 2014 & 2015 & 2016 & 2017 & 2018 & \\
\hline $\begin{array}{l}\text { Ussaha Mikro, Keaid dan } \\
\text { Menenengh (UMKM) }\end{array}$ & 57.895 .721 & 59.262 .772 & 61.651 .177 & 62.922 .617 & 64.194 .0578 & 61.185 .269 \\
\hline Usaha Mikro (UM) & $57,189,393$ & 58.521 .987 & 60.863 .578 & 62.1060900 & 63.350 .222 & $60,406,416$ \\
\hline Ussha Keai| (UK) & 654.222 & 681.522 & 731.047 & 757,090 & 783.132 & 221.403 \\
\hline Ussha Menengeh (UM) & 52.106 & 59.263 & 56.551 & 58.627 & 600702 & 57.450 \\
\hline B Usaha Besar (UB) & 5.066 & 4.987 & 5.370 & 5.460 & 5.550 & 5.287 \\
\hline Total & $57,900.787$ & 59.267 .759 & 61.656 .547 & 62.288 .077 & 64.199 .6066 & 611.190 .555 \\
\hline
\end{tabular}

Sumber : Data Kementrian Koperasi dan UKM

Dari Tabel 1(BPS, 2020a) di atas bisa kita lihat bahwa UMKM jumlahnya rata-rata PDB melebihi usaha besar dari tahun ke tahun, sehingga apabila Pemerintah mampu mengelola dengan baik, maka akan memberikan kontribusi yang signifikan terhadap Penerimaan Negara dari sisi pajak. (BPS, 2020b)

Namun pemberlakuan PP No. 23 tahun2018 ini sifatnya optional(Pudjiastuti, 2013) artinya wajib pajak boleh memilih untuk mengikuti tarif dengan skema final $0,5 \%$, atau menggunakan skema normal yang mengacu pada pasal 17 Undang-Undang Nomor 36 Tahun 2008 tentang Pajak Penghasilan. PP No. 46 tahun 2013 memperlakukan mereka secara khusus, namun adanya PP ini UMKM diperlakukan sama dengan usaha yang lainnya, padahal seharusnya UMKM tersebut harusnya diberikan kesempatan untuk bertumbuh sehingga mampu naik ke tingkatan yang lebih tinggi lagi.(Suwikyo, 2018) Beberapa negara yang lain contohnya China, omzet setara $\mathrm{Rp}$. 60.000 .000 per bulan dikenakan pajak 0\% pada 2020. Sehingga diharapkan Indonesia memberlakukannya dari keuntungan finansial bukan omzet.

Sesuai data dari Menteri Koperasi dan UKM,(Kemenkop, 2020) kontribusi sektor UMKM terhadap total penerimaan pajak masih terbilang minim Rp. 5.000.000.000.000 - Rp. 6.000.000.000.000 / tahun. Jumlah UMKM yang terdaftar dalam sistem perpajakan jumlahnya masih sedikit sekitar 2,3 Juta WP badan dan WP OP. Padahal jumlah UMKM di Indonesia mencapai 60.000 .000 pelaku usaha. (DDTC News Editorial, 2019) maka diharapkan dengan jumlah yang cukup besar ini mampu memberikan kontribusi kepada pendapatan negara yang cukup besar juga. Namun dari faktanya menandakan masih ada potensi yang cukup besar khususnya dari penghasilan UMKM yang belum tergali secara maksimal. Artinya dengan pemberlakuan tarif yang baru ini, Pemerintah bertujuan untuk merangkul UMKM agar masuk ke ranah formal menjadi tax payer

Menurut (Rustiyaningsih, 2011) hambatan terbesar dalam peningkatan pendapatan dari sisi perpajakan adalah faktor kepatuhan wajib pajak itu sendiri, dalam memenuhi kewajiban perpajakan sebagai seorang warga negara yang baik. Sehingga kepatuhan wajib pajak sifatnya mutlak dalam masyarakat yang mana perpajakan kita menerapkan sistem self assessment. Banyak faktor yang mempengaruhi dari perilaku seorang wajib pajak terutama menyangkut kepatuhannya yaitu adalah keadilan pajak itu sendiri, ketika seseorang merasa diperlakukan 
tidak adil dalam hal perpajakan, mereka akan otomatis melakukan penghindaran pemenuhan kewajiban pajaknya. (Berutu, 2013)

Penelitian ini perlu dilakukan karena, Batam merupakan Kota Industri pada awalnya namun, sejak tahun 2015, banyak perusahaan bergerak di bidang galangan kapal yang menyerap banyak tenaga kerja, tidak mendapatkan project sehingga terpaksa harus tutup, kegiatan perekonomian kota Batam sepenuhnya digerakkan oleh UMKM setelahnya (Leo, n.d.). Maka dengan adanya penerapan PP No. 23 tahun 2018 mengenai penurunan tarif $\mathrm{PPh}$ Final ini, pasti berpengaruh terhadap penerimaan negara khususnya pajak final UMKM (Kumparan Bisnis, 2018). Penelitian ini menggunakan objek UMKM yang berlokasi di area kerja KPP Pratama Batam Selatan, yaitu mencakup kecamatan sungai beduk, kecamatan bulang, kecamatan bengkong, kecamatan batam kota, kecamatan sagulung, dan kecamatan batu aji. Wilayah inilah yang dipilih dikarenakan merupakan wilayah yang dianggap cukup padat dalam berbisnis UMKM dengan persebaran penduduk dan industri di kawasan tersebut yang cukup padat juga. Penelitian ini tidak hanya meneliti dari ukuran usahanya melainkan dari jenis komoditasnya yang diduga akan terdapat relevansi terkait dampak penurunan tarif pajak berdasarkan PP No. 23 tahun 2018 terhadap Penerimaan Negara melalui kepatuhan wajib pajak.

\section{Tujuan Penelitian}

1. Menjelaskan dan menguji pengaruh dari Profil Usaha UMKM di Kota Batam terhadap Kepatuhan Wajib Pajak.

2. Menjelaskan dan menguji pengaruh dari Kepatuhan Wajib Pajak terhadap Penerimaan Negara.

3. Menjelaskan dan menguji pengaruh dari Profil Usaha UMKM di Kota Batam terhadap Penerimaan Negara.

4. Menjelaskan dan menguji pengaruh dari Profil Usaha UMKM di Kota Batam terhadap Penerimaan Negara melalui Kepatuhan Wajib Pajak.

\section{KAJIAN PUSTAKA}

\section{Definisi Pajak}

Pajak Menurut Undang-Undang Nomor 6 Tahun 1983 tentang Ketentuan Umum dan Tata Cara Perpajakan sebagaimana telah beberapa kali diubah terakhir dengan
Undang-Undang Nomor 16 Tahun 2009 (Undang-Undang No. 16 Tahun 2009. Ketentuan Umum Dan Tata Cara Perpajakan., 2009), pajak didefinisikan sebagai kontribusi wajib kepada negara yang terutang oleh orang pribadi atau badan bersifat memaksa berdasarkan UU, dengan tidak mendapatkan kontraprestasi secara langsung dan digunakan untuk keperluan negara bagi sebesar-besarnya kemakmuran rakyat.

\section{Pajak Penghasilan}

Dalam mengatur pengenaan paak penghasilan atau $(\mathrm{PPh})$ " Dalam UndangUndang PPh Wajib Pajak dikenakan pajak atas penghasilan yang diperolehnya selama satu tahun pajak atau dapat pula dikenai pajak untuk penghasilan dalam bagian tahun pajak apabila kewajiban pajak dimulai atau berakhir dalam tahun pajak" (Mardiasmo, 2011).

\section{Pengetahuan Wajib Pajak}

Pengetahuan tax knowledge adalah informasi yang digunakan Wajib Pajak sebagai dasar, sebagai keputusan, dan supaya bisa mengambil jalan seperti dalam bidang pajak. WP harus diwajibkan supaya bisa tetap aktif dalam mempelajari aturan dalam perpajakan supaya bisa memenuhi kewajiban perpajakannya sesuai UU Pajak. (Sudrajat \& Ompusunggu, 2015).

\section{Definisi Kepatuhan Wajib Pajak}

Pengertian Kepatuhan Wajib Pajak seperti yang dikemukakan (Maria, 2013)adalah : “ Kepatuhan Wajib Pajak bisa didefinisikan sebagai suatu kondisi yang mana Wajib Pajak memenuhi semua kewajiban perpajakan dan melaksanakan hak perpajakkannya."

\section{Pengertian Penerimaan Pajak}

Pengertian penerimaan pajak adalah dimana besarnya suatu kontribusi yang diterima oleh Negara dari masyarakat yang dimana dipungut berdasarkan Undang-Undang dan hasilnya digunakan untuk kepentingan dan kemakmuran negara adapun contoh penerimaan pajak antara lain yaitu pajak dipungut pusat maupun yang dipungut oleh daerah. (Zuhdi et al., 2019) 


\section{Metode Penghitungan Pajak Penghasilan Menurut Peraturan Pemerintah No. 46 Tahun 2013.}

PP No. 46 tahun 2013 diterbitkan sesuai pertimbangan bahwa untuk memberikan kemudahan kepada WPOP dan Badan yang memiliki peredaran bruto tertentu, perlu memberikan perlakuan tersendiri ketentuan mengenai penghitungan, penyetoran, dan pelaporan Pajak Penghasilan yang terutang. Peraturan Pemerintah No. 46 tahun 2013 mengubah dasar pengenaan objek pajak dari PPh Pasal 17 menjadi PPh Pasal 4 ayat 2 (Final). Sesuai dengan Pasal 3 PP No. 46 Tahun 2013, besaran tarif $\mathrm{PPh}$ Final adalah sebesar $1 \%$ yang dikenakan dari penghasilan bruto. Syarat yang harus dipenuhi dalam pengenaan pajak PP No. 46 Tahun 2013 antara lain :

1. Wajib Pajak orang pribadi atau badan

2. Menerima penghasilan dari usaha tidak termasuk penghasilan dari jasa sehubungan dengan pekerjaan bebas, dengan peredaran bruto tidak melebihi Rp. 4.800.000.000 (empat miliar delapan ratus juta rupiah) dalam 1 (satu) tahun pajak. (Hakim, 2015)

Peraturan Pemerintah ini kemudian dilaksanakan dengan menerbitkan (PERATURAN MENTERI KEUANGAN REPUBLIK INDONESIA NOMOR 107/PMK.011/2013, 2013), pada tanggal 30 Juli 2013. Pasal 3 PMK tersebut, memberikan pedoman untuk menentukan jumlah peredaran bruto, yaitu dari usaha seluruhnya termasuk dari cabang, tidak termasuk peredaran bruto dari :

1. Jasa sehubungan dengan pekerjaan bebas

2. Penghasilan yang diterima atau diperoleh dari luar negeri

3. Usaha yang atas penghasilannya telah dikenakan Pajak Penghasilan yang bersifat final dengan ketentuan peraturan perundangundangan perpajakan tersendiri.

4. Penghasilan yang dikecualikan sebagai objek Pajak.

\section{Peraturan PP No. 23 Tahun 2018}

Tarif $\mathrm{PPh}$ Final sebesar 0,5\% ini bersifat optional. Ini merupakan keputusan Pemerintah untuk meringankan beban para pelaku UMKM. Namun, ketentuan ini bersifat opsional karena wajib pajak dapat memilih untuk mengikuti tarif dengan skema final 0,5\%, atau menggunakan skema normal yang mengacu pada pasal 17 Undang-Undang Nomor 36 Tahun 2008 tentang Pajak Penghasilan.

Sifat opsional ini memberi keuntungan bagi wajib pajak karena:

1. Bagi wajib pajak (WP) pribadi dan badan yang belum dapat menyelenggarakan pembukuan dengan tertib, penerapan $\mathrm{PPh}$ Final $0,5 \%$ memberikan kemudahan bagi mereka untuk melaksanakan kewajiban perpajakan. Sebab, perhitungan pajak menjadi sederhana yakni $0,5 \%$ dari peredaran bruto/omzet. Namun, penerapan $\mathrm{PPh}$ Final memiliki konsekuensi yakni WP tetap harus membayar pajak meski sedang dalam keadaan rugi.

2. Sementara, WP badan yang telah melakukan pembukuan dengan baik dapat memilih untuk dikenai Pajak Penghasilan berdasarkan tarif normal yang diatur pasal 17 UU No. 36 tentang Pajak Penghasilan. Konsekuensinya, perhitungan tarif $\mathrm{PPh}$ akan mengacu pada lapisan penghasilan kena pajak. Selain itu, WP juga terbebas dari PPh bila mengalami kerugian fiskal.

Pengenaan tarif dari PP No. 23 tahun 2018 ini juga mempunyai batas waktu (grace period), jadi tidak seperti PP No. 46 tahun 2013. Batasan waktu yang diberikan pemerintah bagi WP yang ingin memanfaatkan tarif PPh Final $0,5 \%$ adalah:

A. 7 tahun pajak untuk WP orang pribadi.

B. 4 tahun pajak untuk WP badan berbentuk koperasi, CV, atau firma.

C. 3 tahun pajak bagi WP badan berbentuk PT. Setelah batas waktu tersebut berakhir, WP akan kembali menggunakan skema normal seperti diatur oleh pasal 17 UU No.36. Hal ini ditujukan untuk mendorong wajib pajak menyelenggarakan pembukuan dan pengembangan usaha.(Peraturan Pemerintah No.23 Tahun 2018, 2018)

\section{METODE PENELITIAN}

Populasi penelitian ini yaitu pelaku Usaha Mikro, Kecil dan Menengah di wilayah kerja KPP Pratama Batam Selatan yang mencakup kecamatan sungai beduk, kecamatan bulang, kecamatan bengkong, kecamatan batam kota, kecamatan sagulung, dan kecamatan batu aji . Jenis data yang digunakan adalah data primer. Data primer merupakan data yang didapat dari sumber pertama, dari individu seperti hasil wawancara atau hasil pengisian 
kuesioner yang biasa dilakukan peneliti dibantu aplikasi google Form. Data tersebut diperoleh langsung dari pemilik usaha perdagangan mikro, kecil dan menengah yaitu data profil usaha, jumlah pendapatan, dan biaya usaha. Metode yang digunakan adalah metode kuantitatif, dalam penelitian kuantitatif merupakan metode penelitian yang berasaskan pada filsafat positivisme yang digunakan untuk meneliti populasi dan sampel. Metode kuantitatif dipilih untuk mengklasifikasikan penelitian, mengukur dan menganalisis pengaruh penurunan tarif $\mathrm{PPh}$ Final (PPh Pasal 4 ayat 2) terhadap Penerimaan Negara melalui kepatuhan Wajib Pajak di wilayah Batam, khususnya cakupan kerja KPP Pratama Batam Selatan.

Populasi yang ada pada penelitian ini yaitu UMKM di kota Batam secara keseluruhan yang jumlahnya, 81.486 UMKM berdasarkan dari data di Online Data Sistem (ODS) milik Kementrian Koperasi dan Usaha Kecil (UKM RI) (Depkop, 2020). Teknik yang digunakan dalam pengambilan sampel untuk penelitian ini adalah purposive sampling yaitu teknik untuk menentukan sampel penelitian dengan beberapa pertimbangan tertentu yang bertujuan agar data yang diperoleh nantinya bisa lebih representatif.(Sekaran, 2014) Pengambilan sampel dengan menggunakan kriteria tertentu, kriteria sampel pada penelitian ini yaitu pelaku UMKM di Kota Batam dengan cakupan wilayah di area Batam Selatan yaitu Sungai Beduk, Batam Kota, Bulang, Bengkong, Sagulung, Batu Aji, dan bersedia menjadi subyek penelitian Penentuan jumlah sampel yang digunakan mengacu pada teori Hair et al bahwa banyaknya sampel sebagai responden harus disesuaikan dengan banyaknya indikator pertanyaan yang digunakan pada kuesioner, dengan asumsi $\mathrm{n}$ x 5 observed variable (indikator) sampai dengan $\mathrm{n} \times 10$ observed variable (indikator). Dalam penelitian ini jumlah item adalah 12 item pertanyaan yang digunakan untuk mengukur 3 variabel, kisaran sampel adalah 60 responden hingga 120 responden, untuk penelitian ini penulis memutuskan menggunakan sampel sejumlah 120 sampel. Nilai batas maksimum sample. (Sugiyono, 2010)

\section{Kerangka Konseptual}

Kerangka penelitian ditujukan untuk mengidentifikasi dan menjabarkan masalah yang ingin diteliti, berikut gambar mengenai kerangka konseptual :

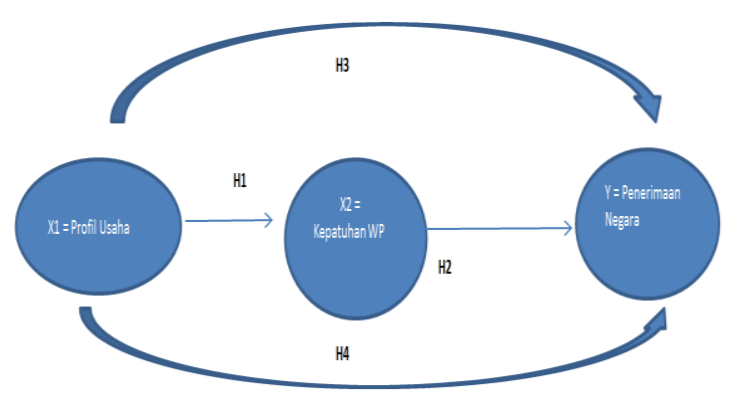

Gambar 1. Kerangka Konseptual

\section{Keterangan :}

H1 : Profil Usaha berpengaruh terhadap Kepatuhan Wajib Pajak

H2 : Kepatuhan Wajib Pajak berpengaruh terhadap Penerimaan Negara

H3 : Profil Usaha berpengaruh terhadap Penerimaan Negara

H4 : Profil Usaha berpengaruh terhadap Penerimaan Negara melalui Kepatuhan Wajib Pajak

\section{Uji Instrumen}

\section{Uji Validitas}

Uji validitas digunakan untuk mengetahui kelayakan butir-butir dalam suatu daftar pertanyaan dalam mendefinisikan suatu variabel. Daftar pertanyaan ini pada umumnya mendukung suatu kelompok variabel tertentu. Uji validitas sebaiknya dilakukan pada setiap butir pertanyaan di uji validitasnya. Hasil $r$ hitung kita bandingkan dengan $r$ tabel dimana $\mathrm{df}=\mathrm{n}-2$ dengan sig 5\%. Jika $\mathrm{r}$ tabel $<\mathrm{r}$ hitung maka valid (Sofyan, 2009)

\section{Uji Reliabilitas}

Reliabilitas (keandalan) merupakan ukuran suatu kestabilan dan konsistensi responden dalam menjawab hal yang berkaitan dengan kontruk-kontruk pertanyaan yang merupakan dimensi suatu variabel dan disusun dalam suatu bentuk kuesioner. Uji reliabilitas dapat dilakukan secara bersama-sama terhadap seluruh butir pertanyaan. Jika nilai alpha $>0,60$ maka reliabel. 


\section{Analisis Data}

Analisis data pada penelitian ini bersifat kuantitatif dengan tujuan untuk menguji hipotesis yang telah ditetapkan. Teknik analisis data yang digunakan oleh peneliti yaitu menggunakan metode analisa jalur (Path Analysis) dengan pengolahannya menggunakan software SPSS Versi 24(Riduwan, 2014).

Analisis jalur ialah (Sarwono, 2007) suatu teknik untuk menganalisis hubungan sebab akibat yang tejadi pada regresi berganda jika variabel bebasnya mempengaruhi variabel tergantung tidak hanya secara langsung tetapi juga secara tidak langsung. Menurut (Sarwono, 2012) analisis jalur merupakan teknik analisis yang digunakan untuk menganalisis hubungan sebab akibat yang inheren antar variabel yang disusun berdasarkan urutan temporer dengan menggunakan koefesien jalur sebagai besaran nilai dalam menentukan besarnya pengaruh variabel independen exogenous terhadap variabel dependen endogenous.

Hipotesis dalam penelitian ini akan dilakukan pengujian dengan menggunakan uji parsial (uji t), utuk menguji tingkat signifikan dari pengaruh variabel independen secara parsial terhadap variabel dependen. Uji $t$ dilakukan dengan cara membandingkan nilai thitung dengan ttabel. Nilai thitung dapat dilihat dari hasil pengolahan data Coefficients. Taraf nyata yang digunakan adalah $\alpha=0,05$ atau $5 \%$. Nilai thitung dibandingkan ttabel dengan ketentuan sebagai berikut ini :

Jika thitung > ttabel, maka H0 ditolak dan Ha diterima

Jika thitung < ttabel, maka H0 diterima dan Ha ditolak

\section{HASIL DAN PEMBAHASAN \\ A. Gambaran Umum Responden}

Kota Batam adalah kota terbesar di Provinsi Kepulauan Riau, Indonesia. Wilayah Kota Batam terdiri dari Pulau Batam, Pulau Rempang dan Pulau Galang dan pulau-pulau kecil lainnya di kawasan Selat Singapura dan Selat Malaka. Pulau Batam, Rempang, dan Galang terkoneksi oleh Jembatan Barelang. Menurut Dinas Kependudukan dan Catatan Sipil Kota Batam per 2015, jumlah penduduk Batam mencapai
1.037.187 jiwa. Batam merupakan bagian dari kawasan khusus perdagangan bebas BatamBintan-Karimun (BBK).("Peraturan Menteri Dalam Negeri Nomor 72 Tahun 2019 Tentang Perubahan Atas Permendagri Nomor 137 Tahun 2017 Tentang Kode Dan Data Wilayah Administrasi Pemerintahan”. Diarsipkan, 2019)

Kota Batam memiliki 12 kecamatan dan 64 kelurahan (dari total 70 kecamatan, 141 kelurahan dan 275 desa di seluruh Kepulauan Riau). Pada tahun 2017, jumlah penduduknya sebesar 1.062.250 jiwa dengan luas wilayahnya $960,25 \mathrm{~km}^{2}$ dan sebaran penduduk 1.106 jiwa/ $/ \mathrm{km}^{2}$ ("Peraturan Menteri Dalam Negeri Nomor 137 Tahun 2017 Tentang Kode Dan Data Wilayah Administrasi Pemerintahan"., 2019)

Pertumbuhan ekonomi Kota Batam yang lebih tinggi dibandingkan dengan laju pertumbuhan ekonomi nasional menjadikan wilayah ini andalan bagi pemacu pertumbuhan ekonomi secara nasional maupun bagi Provinsi Kepulauan Riau. Beragam sektor penggerak ekonomi meliputi sektor komunikasi, sektor listrik, air dan gas, sektor perbankan, sektor industri dan alih kapal, sektor perdagangan dan jasa merupakan nadi perekonomian kota batam yang tidak hanya merupakan konsumsi masyarakat Batam dan Indonesia tetapi juga merupakan komoditas ekspor untuk negara lain. Keberadaan kegiatan perekonomian di Kota ini juga dalam rangka meningkatkan lapangan pekerjaan dan kesejahteraan masyarakat.

\section{B. Kantor Pelayanan Pajak (KPP)}

Kantor Pelayanan Pajak (KPP) adalah unit kerja dari Direktor Jendral Pajak (DJP) yang memberikan bantuan layanan mengenai perpajakan kepada masyarakat luas di Indonesia. Kantor Pelayanan Pajak (KPP) beragam jenisnya ada Kantor Pelayanan Pajak (KPP) Wajib Pajak Besar atau LTO (Large Tax Office) yang hanya difokuskan pada penanganan PPh (Pajak Penghasilan) dan PPN (Pajak Pertambahan Nilai), Kantor Pelayanan Pajak (KPP) Madya atau MTO (Medium Tax Office) fungsinya memberikan pelayanan untuk Wajib Pajak Badan ataupun Perusahaan yang memiliki penghasilan cukup besar di wilayah Kabupaten maupun Kota dan Kantor Pelayanan Pajak (KPP) Pratama atau STO (Small Tax Office) jumlahnya sangat banyak tersebar di 
seluruh Indonesia, yang tugasnya untuk melakukan penyuluhan, pelayanan, pengawasan, wajib pajak di bidang PPh (Pajak Penghasilan), PPN (Pajak Pertambahan Nilai), PPn BM (Pajak penjualan barang mewah) dan pajak tidak langsung, serta KPP Khusus (yang menangani BUMN, PMA, WP Badan, dan perusahaan yang tercatat di BEI)(Maulida, 2018). Sedangkan di Kota Batam ada KPP Pratama Batam Utara, KPP Pratama Batam Selatan dan KPP Madya. Untuk cakupan wilayah kerja KPP Pratama Batam Utara adalah kecamatan belakang pada, kecamatan batu ampar, kecamatan sekupang, kecamatan nongsa, kecamatan galang, kecamatan lubuk baja. Sedangkan untuk cakupan wilayah kerja KPP Pratama Batam Selatan adalah kecamatan sei beduk, kecamatan bulang, kecamatan bengkong, kecamatan batam kota, kecamatan sagulung, kecamatan batu aji. Jumlah dari Wajib Pajak terdaftar di KPP Pratama Batam Selatan selama 4 tahun terakhir sesuai dengan kategori PPh Final (Pasal 4 ayat 2) terkait dengan PP No. 23 Tahun 2018 dan PP No. 46 Tahun 2013 adalah :

Tabel 2. Wajib Pajak Terdaftar yang melakukan pembayaran untuk PP No. 23 Tahun 2018 dan PP No. 46 Tahun 2013

\begin{tabular}{|r|r|r|r|}
\hline Tahun & PP23/46 & \multicolumn{1}{|c|}{ Lainnya } & Tot \\
\hline 2019 & 7.188 & 3.622 & \\
\hline 2018 & 6.080 & 3.483 & \\
\hline 2017 & 6.373 & 2.628 & \\
\hline 2016 & 5.121 & 2.455 & \\
\hline
\end{tabular}

Sumber : Data dari Kantor Pajak Pratama Batam Selatan, 2020

\section{Analisis dan Pembahasan}

Dalam penelitian ini analisis jalur digunakan untuk menguji pengaruh antara variabel Profil Usaha, Kepatuhan Wajib Pajak, dan Penerimaan Negara baik secara langsung maupun secara tidak langsung. Secara analisis, dilakukan dua kali pemodelan untuk menguji pengaruh secara langsung, kemudian untuk menguji pengaruh secara tidak langsung digunakan uji Sobel.(Supranto, 2004)

Jumlah dari Wajib Pajak terdaftar di KPP Pratama Batam Selatan selama 4 tahun terakhir sesuai dengan kategori PPh Final (Pasal 4 ayat 2) terkait dengan PP No. 23 Tahun 2018 dan PP No. 46 Tahun 2013 adalah:
Tabel 2. Wajib Pajak Terdaftar yang melakukan pembayaran untuk PP No. 23 Tahun 2018 dan PP No. 46 Tahun 2013

\begin{tabular}{|r|r|r|r|}
\hline Tahun & PP23/46 & \multicolumn{1}{|c|}{ Lainnya } & \multicolumn{1}{|c|}{ Total } \\
\hline 2019 & 7.188 & 3.622 & 10.810 \\
\hline 2018 & 6.080 & 3.483 & 9.563 \\
\hline 2017 & 6.373 & 2.628 & 9.001 \\
\hline 2016 & 5.121 & 2.455 & 7.576 \\
\hline
\end{tabular}

Sumber : Data dari Kantor Pajak Pratama Batam Selatan, 2020

Tabel 3. Hasil Analisis Jalur Model Pertama Profil Usaha terhadap Kepatuhan Wajib Pajak

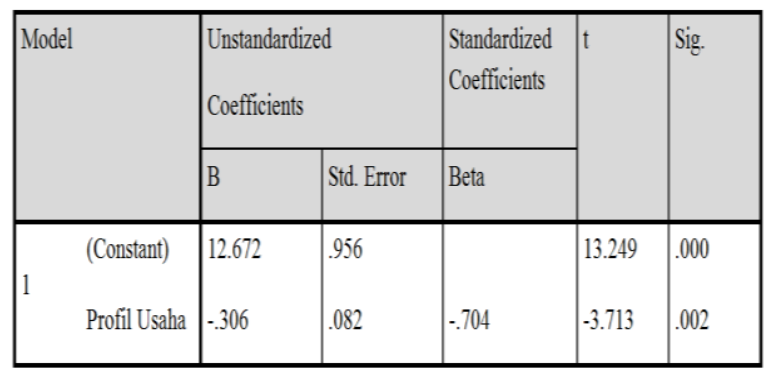

Sumber: Data Penelitian Diolah (2020)

Hasil analisis jalur model pertama antara Profil Usaha terhadap Kepatuhan Wajib Pajak diperoleh koefisien jalur untuk variabel Profil Usaha sebesar $-0,704$ sehingga diperoleh persamaan jalur sebagai berikut:

$$
\begin{aligned}
& \mathrm{z}=\beta_{\mathrm{zx} 1} \mathrm{x}+\mathrm{e} \\
& \mathrm{z}=-0,704 \mathrm{x}+\mathrm{e}
\end{aligned}
$$

Berdasarkan persamaan tersebut dapat dijelaskan sebagai berikut:

a. Koefisien jalur Profil Usaha sebesar -0,704 menunjukkan adanya pengaruh negatif antara Profil Usaha terhadap Kepatuhan Wajib Pajak, artinya semakin tinggi nilai dari variabel profil usaha yang diperoleh dari data jumlah UMKM akan berdampak terhadap semakin rendah nilai dari variabel kepatuhan wajib pajak yang diperoleh dari data jumlah wajib pajak.

Tabel 4. Hasil Analisis Jalur Model Kedua Profil Usaha dan Kepatuhan Wajib Pajak terhadap Penerimaan Negara

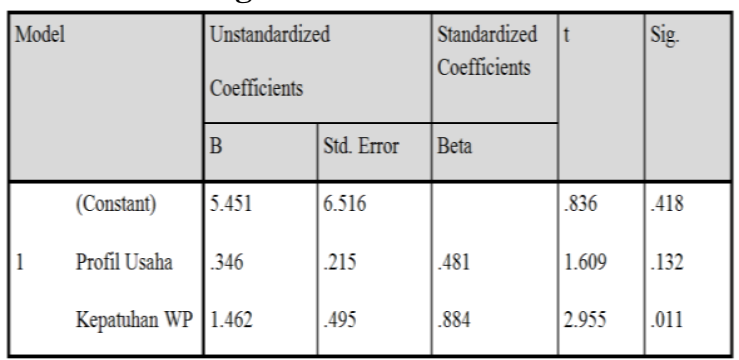

Sumber: Data Penelitian Diolah (2020) 
Hasil analisis jalur model kedua antara Profil Usaha dan Kepatuhan Wajib Pajak terhadap Penerimaan Negara diperoleh koefisien jalur untuk variabel Profil Usaha sebesar 0,481 dan untuk variabel Kepatuhan Wajib Pajak sebesar 0,884 sehingga diperoleh persamaan jalur sebagai berikut:

$$
\begin{aligned}
& y=\beta_{y x 1} x+\beta_{y z} z+e \\
& y=0,481 x+0,884 z+e
\end{aligned}
$$

Berdasarkan persamaan tersebut dapat dijelaskan sebagai berikut:

a. Koefisien jalur Profil Usaha sebesar 0,481 menunjukkan adanya pengaruh positif antara Profil Usaha terhadap Penerimaan Negara, artinya semakin tinggi nilai dari variabel profil usaha yang diperoleh dari data jumlah UMKM akan berdampak terhadap semakin tinggi nilai dari variabel penerimaan negara yang diperoleh dari data penerimaan $\mathrm{PPh}$.

b. Koefisien jalur Kepatuhan Wajib Pajak sebesar 0,884 menunjukkan adanya pengaruh positif antara Kepatuhan Wajib Pajak terhadap Penerimaan Negara, artinya semakin tinggi nilai dari variabel kepatuhan wajib pajak yang diperoleh dari data jumlah wajib pajak akan berdampak terhadap semakin tinggi nilai dari variabel penerimaan negara yang diperoleh dari data penerimaan $\mathrm{PPh}$.

\section{Goodness of Fit Model}

Berikut disajikan hasil goodness of fit model meliputi koefisien determinasi dan koefisien determinasi total.

\section{a. Koefisien Determinasi}

Model penelitian dibentuk oleh variabel Profil Usaha, Kepatuhan Wajib Pajak, dan Penerimaan Negara. Goodness of fit model dilakukan dengan melihat nilai koefisien determinasi terhadap variabel bebas yang diteliti.(Sadjojo, 2011)

Tabel 5. Koefisien Determinasi Model Pertama Profil Usaha terhadap Kepatuhan Wajib Pajak

\begin{tabular}{|l|l|l|l|l|}
\hline Model & $\mathrm{R}$ & $\mathrm{R}$ Square & $\begin{array}{l}\text { Adjusted } \mathrm{R} \\
\text { Square }\end{array}$ & $\begin{array}{l}\text { Std. Error of } \\
\text { the Estimate }\end{array}$ \\
\hline 1 & $.704^{\mathrm{a}}$ & .496 & .460 & .103594 \\
\hline
\end{tabular}

Sumber: Data Penelitian Diolah (2020)

Pengaruh persamaan pertama antara Profil Usaha terhadap Kepatuhan Wajib Pajak diperoleh koefisien determinasi sebesar 0,496, artinya pengaruh terhadap Kepatuhan Wajib Pajak yang dijelaskan dari Profil Usaha mencapai 49,6 persen, sedangkan pengaruh dari faktor lainnya sebesar 50,4 persen.

Tabel 6. Koefisien Determinasi Model Kedua Profil Usaha dan Kepatuhan Wajib Pajak terhadap Penerimaan Negara

\begin{tabular}{|l|l|l|l|l|}
\hline Model & $R$ & R Square & $\begin{array}{l}\text { Adjusted } \\
\text { Square }\end{array}$ & $\begin{array}{l}\text { Std. Error of } \\
\text { the Estimate }\end{array}$ \\
\hline 1 & $.643^{\mathrm{a}}$ & .414 & .324 & .191812 \\
\hline
\end{tabular}

Sumber: Data Penelitian Diolah (2020)

Pengaruh persamaan kedua antara Profil Usaha dan Kepatuhan Wajib Pajak terhadap Penerimaan Negara diperoleh koefisien determinasi sebesar 0,414, artinya pengaruh terhadap Penerimaan Negara yang ditimbulkan dari Profil Usaha dan Kepatuhan Wajib Pajak mencapai 41,4 persen, sedangkan pengaruh dari faktor lainnya sebesar 58,6 persen.

\section{b. Koefisien Determinasi Total}

Pemeriksaan goodness of fit model lainnya dapat menggunakan koefisien determinasi total $\left(\mathrm{Rm}^{2}\right)$ yang menunjukkan model path yang terbentuk mampu mewakili data yang ada. (Riduwan, 2014). Hasil perhitungan koefisien determinasi total $\left(\mathrm{Rm}^{2}\right)$ adalah sebagai berikut:

$$
\begin{aligned}
& \mathrm{Rm}^{2}=1-\left(1-\mathrm{R}_{1}^{2}\right) \times\left(1-\mathrm{R}_{2}^{2}\right) \\
& \mathrm{Rm}^{2}=1-(1-0,496) \times(1-0,414) \\
& \mathrm{Rm}^{2}=1-0,295 \\
& \mathrm{Rm}^{2}=0,705
\end{aligned}
$$

Berdasarkan perhitungan tersebut didapatkan nilai koefisien determinasi total sebesar 0,705 artinya bahwa model path yang terbentuk mampu menjelaskan sekitar $70,5 \%$ variasi data penelitian.

\section{Pengujian Hipotesis}

Berikut disajikan hasil pengujian hipotesis terhadap penelitian antara Profil Usaha, Kepatuhan Wajib Pajak, dan Penerimaan Negara.

Tabel 7. Hasil Pengujian Hipotesis

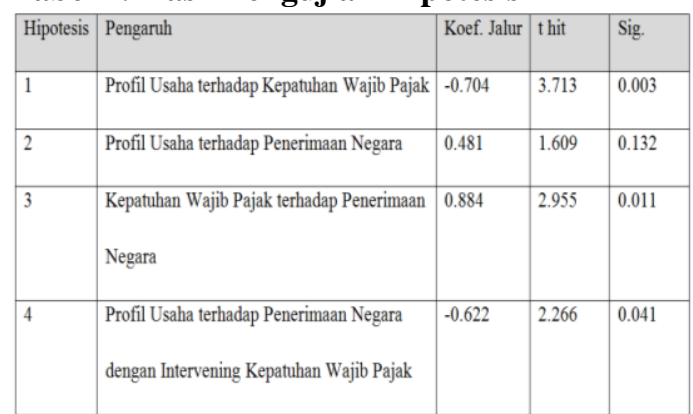

Sumber: Data Penelitian Diolah (2020) 


\section{a. Pengaruh Profil Usaha terhadap} Kepatuhan Wajib Pajak

Hasil pengujian pengaruh antara Profil Usaha terhadap Kepatuhan Wajib Pajak diperoleh nilai koefisien jalur sebesar $-0,704$ dan nilai signifikansi sebesar 0,003 . Hal ini menunjukkan adanya pengaruh negatif signifikan $(\mathrm{p}<0,05)$ antara Profil Usaha terhadap Kepatuhan Wajib Pajak, yang artinya hipotesis diterima. Artinya semakin banyak jumlah profil usaha UMKM di Batam, pengaruhnya tidak berbanding lurus dengan kepatuhan wajib pajak, dikarenakan masih banyak dari para pelaku UMKM di Batam yang masih belum mengenal tentang PP No. 23 tahun 2018, sehingga kewajibannya dari sisi pemenuhan pajaknya masih belum dirasakan oleh Negara secara maksimal. Memang ada pengaruh antara profil usaha dengan kepatuhan wajib pajak, namun pengaruh ini tidak berbanding lurus, yang artinya keinginan Pemerintah dalam hal penerapan PP ini untuk merangkul para pelaku UMKM di Batam, bisa dikatakan masih belum terlalu berhasil diterapkan di Kota ini, dikarenakan masih banyak para pelaku UMKM yang masih belum mendaftarkan dirinya ke ranah formal dalam sistem perpajakan yang ada. Tabel 8. Tingkat Familiaritas Responden terhadap PP No. 23 Tahun 2018

\begin{tabular}{|c|c|c|c|c|c|c|c|}
\hline \multirow{2}{*}{ No. } & \multirow{2}{*}{ Bentuk Usaha } & \multicolumn{5}{|c|}{ Tingkat Familiaritas PP No. 23 Tahun 2018} & \multirow{2}{*}{ Total } \\
\hline & & $\begin{array}{c}\text { Tidak } \\
\text { Familiar }\end{array}$ & $\begin{array}{c}\text { Kurang } \\
\text { Familiar }\end{array}$ & $\begin{array}{c}\text { Cukup } \\
\text { Familiar }\end{array}$ & Familiar & $\begin{array}{l}\text { Sangat } \\
\text { Familiar }\end{array}$ & \\
\hline 1 & WPOP & 33 & 16 & 29 & 6 & 8 & 92 \\
\hline 2 & CV, Firma, Koperasi & 2 & 2 & 4 & 2 & 1 & 11 \\
\hline \multirow[t]{2}{*}{3} & $\mathrm{PT}$ & 0 & 1 & 7 & 6 & 3 & 17 \\
\hline & & & Total & & & & 120 \\
\hline
\end{tabular}

Dari sisi kefamiliaritasan para pelaku UMKM yang dibedakan dari berbagai bentuk usahanya, bisa dilihat bahwa sekitar 53\% WP OP belum mengenal terhadap PP No. 23 tahun 2018, sedangkan CV sebesar 36\% dan PT sebesar 6\% saja yang tidak familiar terhadap penerapan pemberlakuan PP No. 23 tahun 2018 ini, padahal para pelaku UMKM yang ada mayoritas bentuk usaha yang tersebar di wilayah sampel yaitu cakupan kerja Batam Selatan berbentuk WP OP bila dibandingkan dengan CV maupun PT.

\section{b. Pengaruh Profil Usaha terhadap Penerimaan Negara}

Hasil pengujian pengaruh antara Profil Usaha terhadap Penerimaan Negara diperoleh nilai koefisien jalur sebesar 0,481 dan nilai signifikansi sebesar 0,132 . Hal ini menunjukkan adanya pengaruh positif namun tidak signifikan $(p>0,05)$ antara Profil Usaha terhadap Penerimaan Negara, yang artinya hipotesis ditolak. Artinya semakin banyaknya profil usaha UMKM yang ada di Kota Batam tidak mempengaruhi penerimaan negara secara langsung, meskipun seharusnya semakin banyaknya profil usaha UMKM akan mampu meningkatkan penerimaan negara. Hal ini disebabkan adalah masih banyaknya para pelaku UMKM di kota batam yang belum terdaftar di sistem perpajakan di Kota Batam, sehingga tidak mampu meningkatkan penerimaan negara khususnya PPh (Pajak Penghasilan) Final terkait UMKM.

\section{c. Pengaruh Kepatuhan Wajib Pajak terhadap Penerimaan Negara}

Hasil pengujian pengaruh antara Kepatuhan Wajib Pajak terhadap Penerimaan Negara diperoleh nilai koefisien jalur sebesar 0,884 dan nilai signifikansi sebesar 0,011 . Hal ini menunjukkan adanya pengaruh positif signifikan $(\mathrm{p}<0,05)$ antara Kepatuhan Wajib Pajak terhadap Penerimaan Negara, yang artinya hipotesis diterima. Artinya semakin banyaknya wajib pajak yang terdaftar di Kantor Pelayanan Pajak Pratama mampu meningkatkan Penerimaan Negara, status mereka semua merupakan wajib pajak yang aktif atau efektif, untuk melakukan kegiatan dan kewajiban perpajakan, sehingga mampu meningkatkan penerimaan negara untuk jenis PPh Final untuk UMKM terkait PP No. 23 tahun 2018.

\section{d. Pengaruh Profil Usaha terhadap Penerimaan Negara melalui Kepatuhan Wajib Pajak}

Hasil pengujian pengaruh antara Profil Usaha terhadap Penerimaan Negara melalui Kepatuhan Wajib Pajak diperoleh nilai koefisien jalur sebesar $-0,622$ dan nilai signifikansi sebesar 0,041. Hal ini menunjukkan adanya pengaruh negatif signifikan $(p<0,05)$ antara Profil Usaha terhadap Penerimaan Negara melalui Kepatuhan Wajib Pajak, yang artinya hipotesis diterima. 


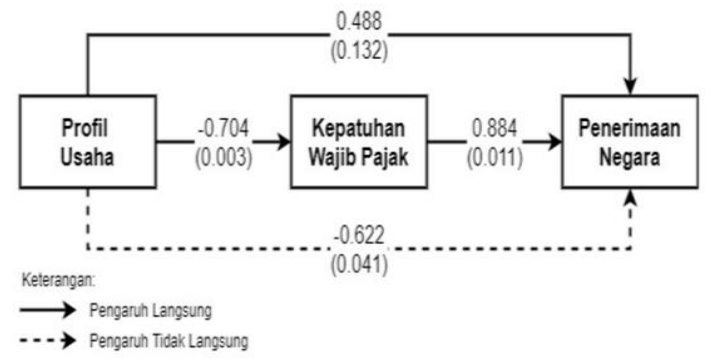

Gambar 2. Diagram Jalur Hubungan antara Profil Usaha, Kepatuhan Wajib Pajak, dan Penerimaan Negara

Sumber : Hasil Pengujian Hipotesis

Artinya Profil Usaha UMKM mampu mempengaruhi penerimaan negara namun harus melalui kepatuhan wajib pajak, pelaku UMKM akan melakukan dan melengkapi, memenuhi kegiatan serta kewajiban pajaknya harus mendaftarkan diri terlebih dulu sebagai wajib pajak yang resmi dalam sistem perpajakan yang ada, tanpa tahapan ini, maka mereka tidak akan mampu melakukan pemenuhan kewajiban perpajakan seperti melaporkan, menyetor ke kas negara sehingga apabila tidak ada tahap pendaftaran diri sebagai wajib pajak, maka tidak akan mampu meningkatkan pemasukan penerimaan negara, namun jumlah para pelaku UMKM di Batam tidak banyak melakukan hal tersebut, jumlah yang terdaftar sebagai UMKM masih belum berbanding lurus dengan jumlah yang mendaftar sebagai wajib pajak, sehingga bertambahnya UMKM di Batam tidak mampu meningkatkan penerimaan negara secara signifikan.

Kepatuhan wajib pajak akan timbul atas dasar didorong oleh kesadaran dari dalam diri wajib pajak itu sendiri, apabila mereka merasa adanya rasa keadilan dalam pemberlakuan penurunan tarif PP No. 23 Tahun 2018, maka tingkat kepatuhan ini juga akan mengalami peningkatan, mengingat di Indonesia, memberikan kebebasan yang bertanggung jawab kepada para wajib pajaknya untuk melaksanakan sistem self assessment dalam kewajiban pajaknya. Maka dari tabel di bawah ini menunjukkan bahwa :
Tabel 9. Respon terhadap pemberlakuan tarif yang baru

\begin{tabular}{ccccc}
\hline \multirow{2}{*}{ No. } & \multirow{2}{*}{ Bentuk Usaha } & \multicolumn{3}{c}{ Penerapan Tarif Terbaru } \\
\cline { 3 - 5 } & & Tidak Setuju & Setuju & \\
\hline 1 & WP OP & 41 & 51 & 92 \\
\hline 2 & CV, Firma, Koperasi & 4 & 7 & 11 \\
\hline 3 & PT & 4 & 13 & 17 \\
\hline \multicolumn{5}{c}{ Total } \\
\hline
\end{tabular}

Sumber : Data diolah, 2020

Pemberlakuan penurunan tarif pajak PP No. 23 tahun 2018 ini sebagian besar wajib pajak menyetujuinya setelah mengetahui adanya perubahan tarif dari $1 \%$ menjadi $0,5 \%$, dengan porsi $55 \%$ setuju untuk para pelaku UMKM yang bentuk usahanya adalah WP OP, dan $63 \%$ pelaku UMKM yang berbentuk CV juga menyetujuinya, sedangkan untuk para pelaku UMKM yang bentuk usahnya adalah PT sebesar $76 \%$. Dengan diberlakukannya tarif yang baru otomatis akan menyebabkan besaran dari pajak terutang dari UMKM terkait $\mathrm{PPh}$ Final (Pasal 4 ayat 2) akan semakin diperingan, tidak memberatkan.

Hal ini juga didukung oleh faktor yang lain dalam variable kepatuhan wajib pajak seperti pengetahuan dari wajib pajak itu sendiri, PP No. 23 tahun 2018 ini sudah memberlakukan tarif yang sangat memperingan para pelaku UMKM, dibandingkan PP No. 46 tahun 2013, namun pengetahuan para wajib pajak mengenai pemberlakuan penerapan PP No. 23 tahun 2018 ini, masih sangat minim, respon yang didapat dari kuesioner yang disebar ke 120 responden, menyatakan bahwa seperti di tabel di bawah ini: Tabel 10. Penyuluhan PP No. 23 Tahun 2018 di Wilayah kerja KPP Pratama Batam Selatan

\begin{tabular}{|c|c|c|c|c|c|c|c|c|c|c|c|c|c|}
\hline \multirow{3}{*}{ I. } & \multirow{3}{*}{ Bentuk Tsaba } & \multicolumn{11}{|c|}{ Lokssiluaha } & \multirow{3}{*}{ Iotal } \\
\hline & & \multicolumn{2}{|c|}{ Kec: Batam Kota } & \multicolumn{2}{|c|}{ Kec.Batu.dij } & \multicolumn{2}{|c|}{ Kec. Bengkiong } & \multicolumn{2}{|c|}{ Kec:Sungei Beduk } & Kec: Bulang & \multicolumn{2}{|c|}{ Kec Sagulung } & \\
\hline & & ada & Tidak: $: d d$ & add & Tidak dda & add & Tidak: Ada & ada & Tiddk:dda & ada Tidak: dda $_{2}$ & $a d a$ & Tidak: $d d a$ & \\
\hline 1 & $\mathbb{N P O P}$ & 16 & 38 & 1 & 1 & 6 & 15 & 0 & 1 & 01 & 0 & 1 & 9 \\
\hline & CV,Fima, & & & & & & & & & & & & \\
\hline ? & Koperasi & 3 & ? & 0 & 1 & 1 & 3 & 0 & 0 & 0 & 1 & 0 & 11 \\
\hline 3 & PI & 5 & 1 & 0 & 1 & 0 & 2 & 0 & 1 & 0 & 1 & 0 & 17 \\
\hline & Total & 2. & 4 & 1 & 9 & 1 & 20 & 1 & $?$ & 1 & $?$ & 1 & 120 \\
\hline
\end{tabular}

Bahwa kegiatan penyuluhan mengenai PP No. 23 tahun 2018, perlu dilakukan lagi dengan lebih intens, untuk para pelaku WP OP, $\mathrm{CV}$, maupun PT yang diwilayah Kecamatan Batam Kota, Kecamatan Batu Aji, Kecamatan Bengkong, Kecamatan Bulang dan Kecamatan Sagulung belum pernah menerima penyuluhan 
terkait PP No. 23 tahun 2018 ini. Dan lebih difokuskan kepada para pelaku UMKM yang bentuk usahanya adalah WP OP.

\section{Perbandingan Antara Penerapan PP No} 46 Tahun 2013 dan Penerapan PP No 23 Tahun 2018 terhadap Besar Pajak UMKM di Wilayah Kerja KPP Pratama Batam Selatan

Analisis perbandingan antara penerapan PP No 46 Tahun 2013 dan Penerapan PP No 23 Tahun 2018 terhadap besar pajak UMKM di Wilayah Kerja KPP Pratama Batam Selatan diuji dengan menggunakan independent sample t-test. Hsail yang diperoleh adalah sebagai berikut:

Tabel 11. Penerimaan PPh 4 ayat 2 (2016 - 2019) di KPP Pratama Batam Selatan

\begin{tabular}{|c|c|c|c|}
\hline Tahun & PP23/46 & Lainnya & Total \\
\hline 2019 & 31.242 .665 .095 & 220.573 .355 .224 & 251.816 .020 .319 \\
\hline 2018 & 36.052 .879 .678 & 166.237 .528 .199 & 202.290 .407 .877 \\
\hline 2017 & 38.865 .565 .327 & 139.381 .328 .030 & 178.246 .893 .357 \\
\hline 2016 & 25.085 .118 .357 & 171.813 .629 .427 & 196.898 .747 .784 \\
\hline $\begin{array}{l}\text { Sumber } \\
2020\end{array}$ & Data dari KPP Pratama Batam Selatan, \\
\hline
\end{tabular}

Tabel 12. Hasil Independent Sample t-test

\begin{tabular}{|l|l|l|l|}
\hline Penerapan PP & Penerimaan Pajak UMKM & T-hitung & P-value \\
\hline PP No 46 Tahun 2013 & $31.975 .341 .842,0$ & \multirow{2}{*}{0.229} & \multirow{2}{*}{0.840} \\
\hline PP N0 23 Tahun 2018 & $33.647 .772 .386,5$ & & \\
\hline
\end{tabular}

Sumber: Data Penelitian Diolah (2020)

Hasil perbandingan antara penerapan

PP No 46 Tahun 2013 dan Penerapan PP No 23 Tahun 2018 terhadap besar pajak UMKM di Wilayah Kerja KPP Pratama Batam Selatan diperoleh nilai rata-rata penerimaan pajak UMKM dengan penerapan PP No 46 Tahun 2013 sebesar 31.975.341.842,0 dan penerapan PP No 23 Tahun 2018 sebesar 33.647.772.386,5 yang artinya terjadi kenaikan penerimaan pajak UMKM.

Hasil independent t-test diperoleh nilai signifikansi sebesar $0,840(\mathrm{p}>0,05)$ yang berarti bahwa tidak terjadi peningkatan signifikan dengan diberlakukannya PP No 23 Tahun 2018 terhadap penerimaan pajak UMKM selama 4 tahun terakhir ini, meskipun meningkat namun belum dirasa masih belum mencapai target. Dikarenakan karena penerapan PP No. 23 Tahun 2018 ini masih tergolong baru, dan perlu adanya kegiatan penyuluhan massal kepada seluruh pelaku UMKM yang ada di Kota Batam khususnya wilayah cakupan kerja KPP Pratama Batam Selatan.

\section{KESIMPULAN}

1. Profil Usaha UMKM di Kota Batam memiliki pengaruh signifikan terhadap kepatuhan wajib pajak dengan nilai signifikansi sebesar 0,003 .

2. Profil Usaha UMKM di Kota Batam tidak berpengaruh signifikan terhadap Penerimaan Negara khususnya PPh 4 ayat 2 (PPh Final) untuk UMKM, dengan nilai signifikansi sebesar $0,132(\mathrm{p}>0,05)$

3. Kepatuhan Wajib Pajak berpengaruh signifikan terhadap Penerimaan Negara khususnya PPh 4 ayat 2 (PPh Final) untuk UMKM di Kota Batam, dengan nilai signifikan sebesar 0,011.

4. Profil Usaha UMKM berpengaruh signifikan terhadap Penerimaan Negara khususnya PPh 4 ayat 2 (PPh Final) untuk UMKM di Kota Batam, melalui Kepatuhan Wajib Pajak sebesar 0,041 .

Sehingga dengan adanya hasil dari penelitian ini, masih banyak pelaku UMKM yang jumlahnya cukup besar, yang nantinya mampu menambah penerimaan negara, asalkan mereka sebagai pelaku UMKM sendiri terdaftar di sistem perpajakan, untuk mendorong mereka mendaftarkan diri, adalah memberikan penyuluhan mengenai PP No. 23 Tahun 2018 secara lebih intens lagi, khususnya ke wilayahwilayah cakupan kerja di kecamatan yang ada di Batam Selatan, untuk menambah pengetahuan para pelaku UMKM mengenai pemberlakuan tarif yang baru, sehingga mampu mendorong para pelaku UMKM yang belum terdaftar untuk mendaftarkan diri sebagai wajib pajak, khususnya WP OP yang jumlahnya sangat besar sekali di Batam.

\section{TERIMA KASIH}

Terima kasih kepada Direktorat Riset dan Pengabdian Masyarakat, Direktorat Jenderal Penguatan Riset dan Pengembangan yang telah memberikan dukungan terhadap pelaksanaan penelitian ini melalui hibah penelitian KEMENRISTEKDIKTI Tahun Anggaran 2020. 


\section{DAFTAR PUSTAKA}

Berutu, D. A. (2013). Persepsi Keadilan Pajak Terhadap Perilaku Kepatuhan Wajib Pajak Orang Pribadi (Wpop). 265-274.

BPS. (2020a). Produk Domestik Bruto dan Per Kapita atas dasar harga konstan. https://www.bps.go.id/statictable/2015/09 $129 \quad 00: 00: 00 / 1866 /$ perkembanganproduk-domestik-bruto-dan-produkdomestik-bruto-per-kapita-atas-dasarharga-konstan-2010-2010-2016.html

BPS. (2020b). Tabel Perkembangan UMKM. https://www.bps.go.id/statictable/2014/01 /30/1322/tabel-perkembangan-umkmpada-periode-1997--2013.html

DDTC News Editorial. (2019, August 20). Berapa jumlah wajib pajak dan tingkat kepatuhannya? DDTC News. ? https://news.ddtc.co.id/berapa-jumlahwajib-pajak--tingkat-kepatuhannya-cekdi-sini-16815 diakses pada 01 Agustus 2020.

Depkop. (2020). Online Data Sistem (ODS) di Kementerian Koperasi dan Usaha Kecil Menengah (UKM). http://www.depkop.go.id/ diakses tanggal 01 Agustus 2020.

Peraturan Pemerintah No.23 tahun 2018, Jaringan Dokumentasi dan Informasi Hukum Kementerian Sekretariat Negara (2018).

https://www.pajak.go.id/id/peraturanpemerintah-nomor-23-tahun-2018

Diakses 22 Juli 2019. Sumber: Jaringan Dokumentasi dan Informasi Hukum Kementerian Sekretariat\%0ANegara\%0A

Undang-Undang No. 16 tahun 2009. Ketentuan Umum dan Tata Cara Perpajakan., (2009). http://www.dpr.go.id/dokjdih/document/u u/UU_2009_16.pdf

Hakim, F. dan G. B. N. (2015). Analisis Penerapan PP No. 46 Tahun 2013 tentang Pajak Penghasilan UMKM terhadap Tingkat Pertumbuhan Wajib Pajak dan Pertumbuhan Wajib dan Penerimaan $\mathrm{PPh}$ Pasal 4 ayat (2) pada KPP Pratama Manado. Jurnal EMBA Universitas Sam Ratulangi Manado. https://ejournal.unsrat.ac.id/index.php/em ba/article/view/7553

"Peraturan Menteri Dalam Negeri Nomor 137
Tahun 2017 tentang Kode dan Data Wilayah Administrasi Pemerintahan"., (2019).

https://www.kemendagri.go.id/files/201905/Kode\&Data Wilayah/Permendagri 137-2017.pdf

PERATURAN MENTERI KEUANGAN REPUBLIK INDONESIA NOMOR 107/PMK.011/2013, (2013). https://jdih.kemenkeu.go.id/fullText/2013 /107 PMK.011 2013Per.htm

Kemenkop. (2020). Perkembangan data UMKM. http://www.depkop.go.id/dataumkm

"Peraturan Menteri Dalam Negeri Nomor 72 Tahun 2019 tentang Perubahan atas Permendagri nomor 137 Tahun 2017 tentang Kode dan Data Wilayah Administrasi Pemerintahan". Diarsipkan, (2019).

https://www.kemendagri.go.id/page/read/ 48/peraturan-menteri-dalam-negeri-no72tahun-2019

Kumparan Bisnis. (2018). Negara akan kehilangan Rp. 1,5 Triliun dari penurunan tarif pajak UMKM. Kumparan Bisnis. https://kumparan.com/@ kumparanbisnis/ negara-bakal-kehilangan-rp-1-5-triliundari-penurunan-tarif-pajak-umkm

Leo. (n.d.). UMKM, Harapan Baru Perekonomian Batam. Batampos.Co.Id. https://batampos.co.id/2018/10/15/umkm -harapan-baru-perekonomian-batam/

Mardiasmo. (2011). Perpajakan Edisi Revisi (Revisi). Andi.

Maria, D. (2013). Delli Maria Jurnal Bisnis Darmajaya Vol. 01 No. 01, Maret 2013. Bisnis Darmajaya, 01(01).

Maulida, R. (2018). KPP sejarah singkat dan perkembangan serta jenis-jenis. Online Pajak. https://www.online-pajak.com/kpp oleh Rani Maulida pada 30 Agustus 2018

Pudjiastuti, S. L. (2013). Simplikasi Regulasi Pajak untuk UMKM. Direktorat Jendral Pajak.

https://pajak.go.id/artikel/simplifikasireg ulasi- pajak-untuk-umkm

Riduwan, dan E. A. K. (2014). Cara Menggunakan dan Memaknai Path Analisis. Alfabeta. 
Rustiyaningsih, S. (2011). Faktor-faktor yang mempengaruhi kepatuhan wajib pajak. Jurnal Widya Warta No. 002 Fakultas Ekonomi Universitas Katolik Widya Mandala.

http://eprints.ums.ac.id/37129/14/NASK

AH PUBLIKASI.pdf\%0A\%0A

Sadjojo, N. (2011). Metode Analisis Jalur (Path Analysis) dan Aplikasinya. Pustaka Sinar Harapan.

Sarwono, J. (2007). Analisis Jalur Untuk Riset Bisnis Dengan SPSS. Andi.

Sarwono, J. (2012). Path Analisis. PT Elex Media Komputindo.

Sekaran, U. (2014). Reserch Methods For Bussiness (Metodologi Penelitian untuk Bisnis) Buku I (4th ed.). Salemba Empat.

Setiawan, D. A. (n.d.). Dinilai 'Tahan Banting' Kontribusi UMKM ke Pajak diharapkan naik. News. Dtc. https://news.ddtc.co.id/dinilai-tahanbanting-kontribusi-umkm-ke-pajakdiharapkan-naik-19020?page_y $=1300$

Sofyan, Y. dan H. K. (2009). SPSS Complete. Salemba Infotek.

Sudrajat, A., \& Ompusunggu, A. P. (2015). Pemanfaatan teknologi Informasi, Sosialisasi Pajak, Pengetahuan Perpajakan, dan Kepatuhan Pajak I N F O A R T I K E L. Jurnal Riset Akuntansi Dan Perpajakan JRAP, 2(2), 193-202.

Sugiyono. (2010). Metode Penelitian Pendidikan Pendekatan Kuantitatif, kualitatif, dan $R \& D$. Alfabeta.

Supranto, J. (2004). Analisis Multivariat Arti dan Interpretasi. PT. Rineka Cipta.

Suwikyo, E. (2018). Insentif Pajak UMKM $0,5 \%$ dinilai belum pro usaha mikro. Ekonomi Bisnis. https://ekonomi.bisnis.com/read/2018062 7/9/810292/insentif-pajak-umkm-05dinilai-belum-pro-usaha-mikro diakses pada 02 Juni 2019

Zuhdi, M. I., Suryadi, D., \& Yuniati. (2019). Model Hubungan Kausal Kesadaran, Pelayanan, Kepatuhan Wajib Pajak dan Pengaruhnya Terhadap Kinerja Penerimaan Pajak: Suatu Survei Di Wilayah Jawa Timur. Ilmiah MEA, 3(1), 116-135. https://doi.org/10.31955/mea.vol3.iss1.pp $116-135$ 